\title{
Bacillus siralis sp. nov., a novel species from silage with a higher order structural attribute in the 16S rRNA genes
}

\footnotetext{
1 Department of Biotechnology, Royal Institute of Technology, S-100 44 Stockholm, Sweden

2 Department of Biological Sciences, Heriot-Watt University, Edinburgh EH14 4AS, UK
}

\author{
Bertil Pettersson, ${ }^{1}$ Shyama K. de Silva, ${ }^{2}$ Mathias Uhlén ${ }^{1}$ \\ and Fergus G. Priest ${ }^{2}$
}

Author for correspondence: Fergus G. Priest. Tel: +44 131451 3464. Fax: +44 1314513009. e-mail: f.g.priest@hw.ac.uk

Keywords: Bacillus siralis, taxonomy, phylogeny, 16S rRNA, rRNA extension

\section{INTRODUCTION}

Previous studies on bacterial biodiversity in grassland soils using molecular biology techniques have revealed that most of the $16 \mathrm{~S}$ rDNA sequences obtained originated from bacterial taxa that had either not been cultured in vitro or had not been characterized at the 16S rDNA level (Borneman et al., 1996; Felske et al., 1998). In these studies, many of the clones were phylogenetically related to members of the genus Bacillus. Recently, several novel Bacillus strains have been isolated from grass silage which appear to be phylogenetically similar to the grassland soil clones (De Silva et al., 1998). Sequence analysis of the $16 \mathrm{~S}$ rRNA genes of some of these organisms revealed that

Abbreviation: RAPD, randomly amplified polymorphic DNA.

The GenBank/EMBL/DDBJ accession number for the 16S rRNA sequence of Bacillus siralis strain $171544^{\top}$ is AF071856. several possible new species of the genus Bacillus were present in the silage (De Silva et al., 1998).

One of the silage isolates (strain $171544^{\mathrm{T}}$ ) showed an unusually long extension to the 16S rRNA gene located in the penultimate loop of the 16S rRNA molecule. This type of macro-heterogeneity has been rarely reported in Gram-positive bacteria, for example in Clostridium paradoxum (Rainey et al., 1996) and Desulfotomaculum australicum (Patel et al., 1992). However, insertions in both the $16 \mathrm{~S}$ and $23 \mathrm{~S}$ rRNA genes have been noted in several Gram-negative bacteria including Campylobacter helveticus (Linton et al., 1994a), Campylobacter sputorum (Van Camp et al., 1993), Helicobacter canis (Linton et al., 1994b), Leptospira (Ralph \& McClelland, 1994), salmonellae (Burgin et al., 1990; Mattatall \& Sanderson, 1998) and Yersinia enterocolitica (Skurnik \& Toivanen, 1991).

In this study, four more isolates resembling strain 
$171544^{\mathrm{T}}$ have been isolated from other silage samples and subjected to biochemical, morphological and genotypic characterizations. All five strains were genotypically and phenotypically homogeneous, shared the same unique element in the 16S rRNA genes and were distinct from all other species of the genus Bacillus.

\section{METHODS}

Strains and culture conditions. Bacillus strain $171544^{\mathrm{T}}$, an isolate from silage, has been described previously (De Silva et al., 1998). Similar strains were isolated from freeze-dried silage samples (kindly provided by Fritz Lembke, TetraPak $\mathrm{GmbH}$, Stuttgart, Germany). Lyophilized silage (1 g) was suspended in $1 \mathrm{ml}$ sterile water, heated at $100{ }^{\circ} \mathrm{C}$ for $90 \mathrm{~min}$ and diluted to $10^{-1}$ and $10^{-2}$ in sterile water. Aliquots $(50 \mu 1)$ were spread on NYSM agar (100 ml nutrient agar containing $0.5 \mathrm{~g}$ yeast extract $1^{-1}$ and $1 \mathrm{ml}$ of a solution containing $5 \times 10^{-5} \mathrm{M} \mathrm{MnCl}_{2}, 7 \times 10^{-4} \mathrm{M} \mathrm{CaCl}_{2}, 1 \times 10^{-3} \mathrm{M} \mathrm{MgCl}_{2}$ ) and brain heart infusion (BHI; Oxoid) agar plates and incubated for $24-48 \mathrm{~h}$ at $37^{\circ} \mathrm{C}$. Colonies from both media resembling Bacillus strain $171544^{\mathrm{T}}$ were purified on NYSM agar and examined microscopically after Gram-staining. Isolates appearing as slender rods with a subterminal, oval endospore in a swollen sporangium were retained. Strains on NYSM agar were stored at room temperature and subcultured every 2 weeks. Stock cultures were kept at $-70^{\circ} \mathrm{C}$ in BHI broth containing $20 \%$ glycerol $(\mathrm{v} / \mathrm{v})$ and in freeze-dried form at room temperature. Reference strains from our culture collection included: Bacillus circulans DSM $11^{\mathrm{T}}$, Bacillus firmus DSM $12^{\mathrm{T}}$, Bacillus pumilus 5HR (isolated from silage), Bacillus sporothermodurans $\mathrm{M} 215^{\mathrm{T}}$ and Bacillus subtilis DSM $10^{\mathrm{T}}$.

Morphological and physiological characterization. Cellular morphology was determined from Gram-stained cultures grown for $24 \mathrm{~h}$ on NYSM agar at $37^{\circ} \mathrm{C}$. Spore morphology was determined after a further $24-h$ incubation using phasecontrast microscopy. The physiological tests shown in Table 1 were conducted according to recognized methods (Gordon et al., 1973), with the exceptions that aesculin and gelatin hydrolysis were detected according to Priest et al. (1988) and a prototype identification kit for Bacillus species (Microbact 36B; Medvet Science) was used for the detection of arginine dihydrolase and acid production from carbohydrates. The latter is based on indicator (bromocresol purple) change due to acid production from sugar fermentation during a 3-d incubation period (similar to the standard methods for Bacillus; Gordon et al., 1973). The correlation of this method with acid production in ammonium salt sugar medium (Gordon et al., 1973) has been evaluated and confirmed by examination of reference strains in the Microbact 36B system (data not shown). Strains were examined for resistance to antibiotics using impregnated discs (Mast Groups) placed on NYSM agar plates seeded with a light lawn of bacteria and incubated at $37^{\circ} \mathrm{C}$ for $24 \mathrm{~h}$. A distinct inhibition zone indicated susceptibility to the antibiotic.

Molecular methods. Chromosomal DNA was purified as described previously (Aquino de Muro et al., 1992). PCR reactions were typically performed in a final volume of $100 \mu \mathrm{l}$ using $80 \mathrm{pmol}$ of each primer, $50 \mathrm{ng}$ of template and $1 \mathrm{mM}$ of each dNTP. Taq DNA polymerase (Bioline) was added after the initial denaturation at $95{ }^{\circ} \mathrm{C}$ for $10 \mathrm{~min}$.

Table 1. Distinctive phenotypic properties of $B$. siralis and phylogenetically related species

,$+>90 \%$ strains positive;,$-<10 \%$ strains positive; v, 11-89\% strains positive; NT, not tested. Data taken from the following references: B. benzoevorans, Pichinoty et al. (1984); B. circulans and B. firmus, Claus \& Berkeley (1986). Data for $10 \% \mathrm{NaCl}$ and growth at $50^{\circ} \mathrm{C}$ from Priest et al. (1988), data for arginine dihydrolase, this study.

\begin{tabular}{|c|c|c|c|c|}
\hline Characteristic & B. benzoevorans & B. circulans & B. firmus & B. siralis \\
\hline Cell shape & Filamentous & Rods & Rods & Rods \\
\hline Spore shape & Oval & Oval & Oval & Oval \\
\hline Swollen sporangia & - & + & - & + \\
\hline Anaerobic growth & - & + & - & - \\
\hline Nitrate reduction & + & $\mathrm{V}$ & + & + \\
\hline Arginine dihydrolase & NT & - & - & $\mathrm{V}$ \\
\hline \multicolumn{5}{|l|}{ Acid from: } \\
\hline Arabinose & - & + & - & - \\
\hline Glucose & - & + & + & - \\
\hline Mannitol & - & + & + & - \\
\hline Xylose & - & + & - & - \\
\hline Acetylmethylcarbinol production & - & - & - & - \\
\hline \multicolumn{5}{|l|}{ Hydrolysis of: } \\
\hline Aesculin & NT & + & - & + \\
\hline Casein & NT & - & + & + \\
\hline Gelatin & - & + & + & + \\
\hline Starch & - & + & + & - \\
\hline Use of citrate & $\mathrm{V}$ & - & - & - \\
\hline \multicolumn{5}{|l|}{ Growth in: } \\
\hline $5 \% \mathrm{NaCl}$ & - & + & + & + \\
\hline $10 \% \mathrm{NaCl}$ & - & - & + & - \\
\hline Growth at $50^{\circ} \mathrm{C}$ & - & - & - & + \\
\hline
\end{tabular}


Reactions comprised 25 cycles of $94{ }^{\circ} \mathrm{C}$ for 1 min, annealing at the relevant temperature for $1.5 \mathrm{~min}$ and extension at $72{ }^{\circ} \mathrm{C}$ for $1.5 \mathrm{~min}$, with a final extension at $72{ }^{\circ} \mathrm{C}$ for $5 \mathrm{~min}$ before the reduction of the reaction temperature to $4{ }^{\circ} \mathrm{C}$. Products were electrophoresed in $2 \%$ agarose gels at $60 \mathrm{~V}$ for $2 \mathrm{~h}$ using Tris/acetate buffer. Primers (MWG Biotech) were prepared to amplify from the $5^{\prime}$-end of the $16 \mathrm{~S}$ rRNA gene ( $8 \mathrm{~F} ; 5^{\prime}$-AGA GTT TGA TCM TGG CTC AG-3') into the insertion sequence in helix 49 (1452R; 5'-GTG GTT TCA CTG AAT TTC CGA C-3') with an annealing temperature of $58{ }^{\circ} \mathrm{C}$ and to amplify the internal section of helix 49 [primers $1372 \mathrm{~F}$ (5'-CAC ACC GCC CGT CAC ACC-3') and 1504R (5'-GAC TTC ACC CCA ATC ATC$\left.3^{\prime}\right)$ ] with an annealing temperature of $55^{\circ} \mathrm{C}$. Randomly amplified polymorphic DNA (RAPD) patterns were prepared using the primer $5^{\prime}-\mathrm{CCG}$ AGT CCA-3' and $50 \mathrm{ng}$ chromosomal DNA as template. Denaturation at $95^{\circ} \mathrm{C}$ for $10 \mathrm{~min}$ was followed by 30 cycles of $95^{\circ} \mathrm{C}$ for $45 \mathrm{~s}, 30^{\circ} \mathrm{C}$ for $10 \mathrm{~s}$ ramped at $1{ }^{\circ} \mathrm{C}$ per $2 \mathrm{~s}$ to $72{ }^{\circ} \mathrm{C}$ for 2 min and a final hold at $72{ }^{\circ} \mathrm{C}$ for $7 \mathrm{~min}$. Products were analysed in $1.5 \%$ agarose gels using Tris/acetate buffer.

Phylogenetic analysis. The virtually complete sequence of the 16S rRNA genes of strain $171544^{\mathrm{T}}$ was determined by a solid-phase DNA sequencing method as described previously (De Silva et al., 1998). The sequences were aligned manually by using the Genetic Data Environment software (GDE; Smith, 1992). The alignment comprised previously described 16S rRNA gene sequences from Bacillus species retrieved from GenBank invoking the gapped-BLAST option (Altschul et al., 1997) at the NCBI home page and those available in an alignment format from RDP, the Ribosomal Database Project (Maidak et al., 1999; RDP-II, 1999). Phylogenetic calculations were performed by using algorithms implemented in the phylogenetic program package PHYLIP version 3.573 (Felsenstein, 1993). The tree was derived by using the neighbour-joining program (Saitou \& Nei, 1987) from a distance matrix corrected for multiple substitutions at single locations by the one-parameter model of Jukes \& Cantor (1969).

Nucleotide accession numbers. The GenBank accession numbers for the $16 \mathrm{~S}$ rRNA sequences of the reference strains used for phylogenetic calculations are given in Fig. 2.

\section{RESULTS}

\section{Isolation of strains similar to Bacillus 171544}

Strain $171544^{\mathrm{T}}$ was originally isolated after prolonged heat treatment of silage samples (De Silva et al., 1998). The same enrichment procedure was used here $(90 \mathrm{~min}$ at $100{ }^{\circ} \mathrm{C}$ ) and colonies of aerobic, endospore-forming bacteria were selected after incubation on BHI and NYSM agars for $2 \mathrm{~d}$. Four isolates with cellular and colonial morphology similar to that of strain $171544^{\mathrm{T}}$ were purified on NYSM agar, retained and labelled $1 \mathrm{HR}, 2 \mathrm{HR}, 3 \mathrm{HR}$ and $4 \mathrm{HR}$. These bacteria were obtained from two separate silage samples. Presumptive identification as members of the same taxon as strain $171544^{\mathrm{T}}$ was obtained by PCR amplification using a universal forward primer, which recognized the 5 '-end of the 16S rRNA gene and a reverse primer targeted to a significantly protruding structural feature in the 16S rRNA gene. This insertion is positioned near the $3^{\prime}$-end of the 16S rRNA gene of strain $171544^{\mathrm{T}}$ (De Silva et al., 1998). An amplification product of (a)

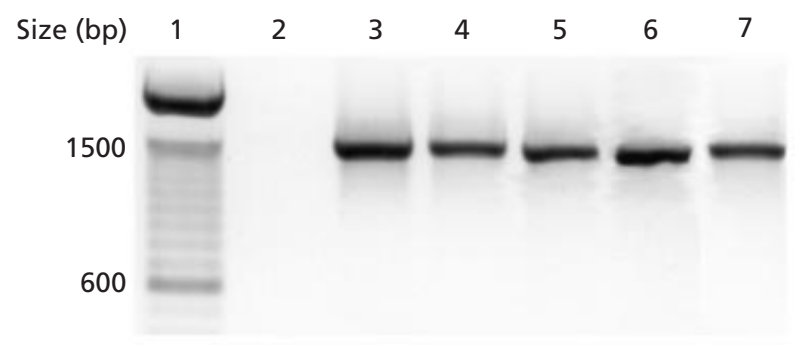

(b)

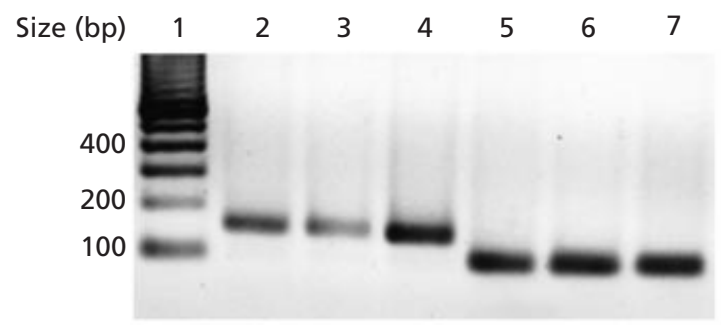

Fig. 1. Agarose gel electrophoresis of $P C R$ products from $16 \mathrm{~S}$ rRNA genes of strain $171544^{\top}$ and related bacteria using (a) a forward primer to the proximal end of the gene and a reverse primer in the extension to helix 49 and (b) forward and reverse primers flanking the extension to helix 49 (see text for details). (a) Lanes: 1, $1 \mathrm{kbp}$ ladder; 2, B. pumilus $5 \mathrm{HR}$; 3, strain $171544^{\mathrm{T}}$; 4, 1HR; 5, 2HR; 6, 3HR; 7, 4HR. (b) Lanes: 1, 100-bp ladder, 2, strain $171544^{\top} ; 3,1 \mathrm{HR}, 4,2 \mathrm{HR} ; 5, B$. pumilus $5 \mathrm{HR} ; 6, B$. subtilis DSM $10^{\top} ; 7, B$. sporothermodurans $\mathrm{M}^{\top} 15^{\top}$.

about $1.5 \mathrm{~kb}$ was produced when DNAs from strains $171544^{\mathrm{T}}, 1 \mathrm{HR}, 2 \mathrm{HR}, 3 \mathrm{HR}$ and $4 \mathrm{HR}$ were used as template but not with DNA from typical species of Bacillus including $B$. pumilus 5HR (Fig. 1a), $B$. sporothermodurans $\mathrm{M} 215^{\mathrm{T}}$ or $B$. subtilis DSM $10^{\mathrm{T}}$ (data not shown). This was strong evidence for the presence of the insertion in the four new silage isolates. Similarly, the insertion could be recognized using primers that flanked this protrusion, thus resulting in amplification products from strain $171544^{\mathrm{T}}$ and similar isolates being larger (about $150 \mathrm{bp}$ ) than those from other Bacillus species (about 100 bp; Fig. 1b). Subsequent sequencing of these products confirmed that insertions in strains $1 \mathrm{HR}, 2 \mathrm{HR}, 3 \mathrm{HR}$ and $4 \mathrm{HR}$ were identical to that found in strain $171544^{\mathrm{T}}$.

\section{Molecular phylogeny}

The virtually complete $16 \mathrm{~S}$ rDNA sequence of strain $171544^{\mathrm{T}}$ was compared with sequences of related organisms. Phylogenetic trees were constructed using different data sets as obtained from a starting alignment comprising about 400 published and unpublished Bacillus-related 16S rRNA gene sequences. Several subsets were selected for phylogenetic calculations and each was compensated by removing gaps, ambiguously aligned positions and positions for which a certain nucleotide composition could not be observed in more than half of the sequences. Despite slight shifts in branching order, strain $171544^{\mathrm{T}}$ consistently clustered 


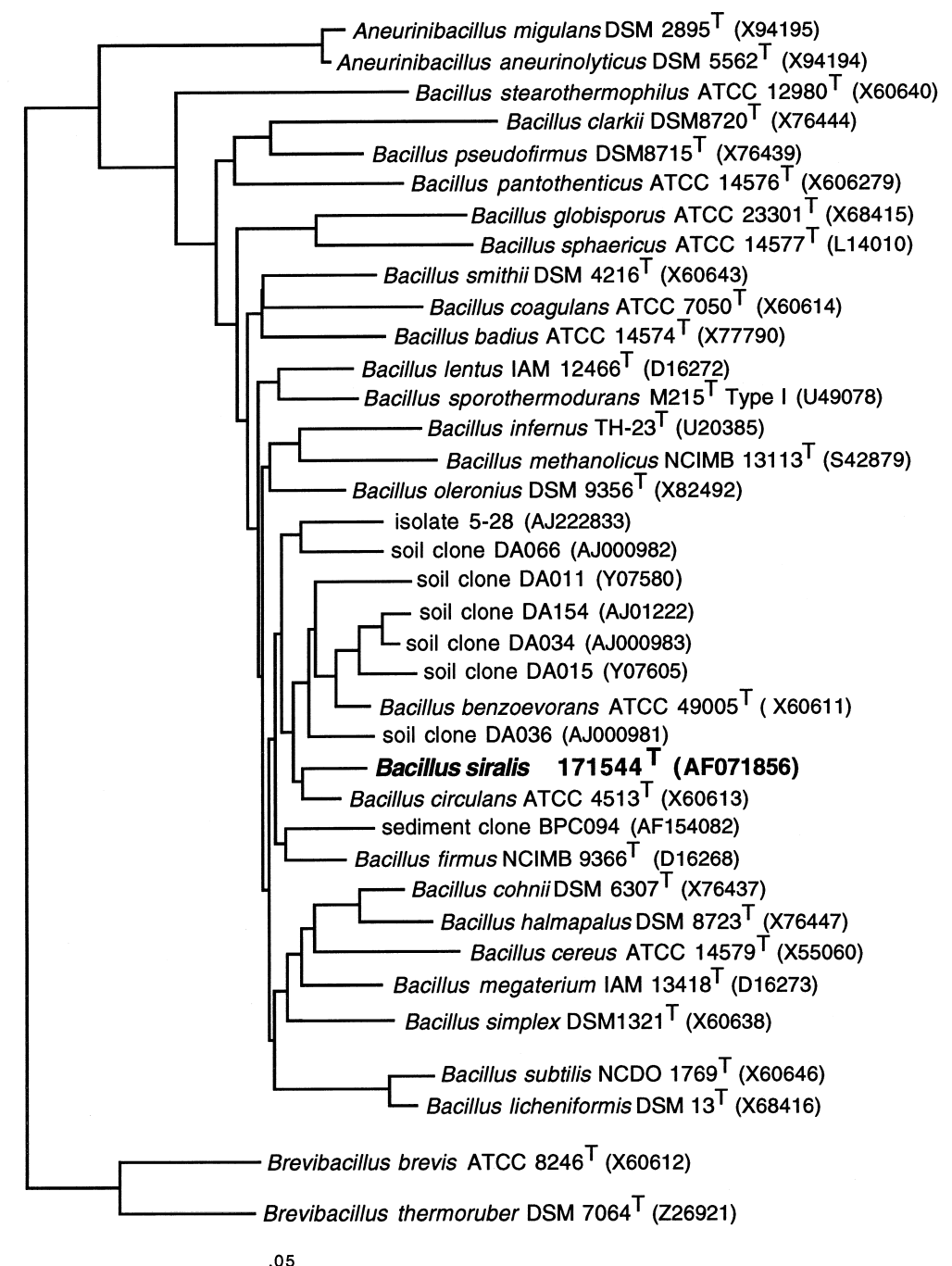

Fig. 2. An evolutionary distance tree showing the phylogenetic placement of Bacillus siralis strain $171544^{\top}$ and its relatives among the members of the genus Bacillus and closely grouping 165 rDNA clone sequences as obtained from soil and aquatic niches. The tree was constructed from a distance matrix corrected by the method of Jukes \& Cantor (1969) by using the neighbour-joining program of Saitou \& Nei (1987). The scale bar denotes the number of substitutions per nucleotide position. Brevibacillus brevis ATCC $8246^{\top}$ and Brevibacillus thermoruber DSM $7064^{\top}$ served as outgroups. Accession numbers are given in parentheses. with Bacillus benzoevorans, B. circulans and B. firmus in all trees, confirming the relatedness of these taxa. A representative phylogenetic tree inferred by the neighbour-joining method (Saitou \& Nei, 1987) from a distance matrix corrected for multiple nucleotide substitutions at single locations by the one-parameter model of Jukes \& Cantor (1969) is shown in Fig. 2. Bootstrap analysis indicated that the region of the tree containing $B$. firmus and relatives has weak statistical support for the different branching orders and bootstrap values were, therefore, not included at the individual nodes of the dendrogram.

From 16S rRNA gene sequence similarities, strain $171544^{\mathrm{T}}$ was most closely related to $B$. circulans (similarity value of $97.2 \%$ ) and $B$. firmus $(96.3 \%$ ) and less so to the filamentous bacterium $B$. benzoevorans $(95.9 \%)$. Besides the clustering to known Bacillus species, strain $171544^{\mathrm{T}}$ showed relatively close relationships to a set of $16 \mathrm{~S}$ rDNA clones enriched from grassland soil (Felske et al., 1998), in particular, soil clones DA036 and DA066, and the sediment clone BPC094 showed $96 \cdot 1,95.5$ and $95.7 \%$ similarity to strain $171544^{\mathrm{T}}$, respectively. Because the closest phylogenetic relatives of strain $171544^{\mathrm{T}}$ lay on the borderline of $97 \%$ rRNA similarity, which is generally recognized as the upper limit for separate speciation, the silage isolates were compared with the type strains of $B$. circulans and B. firmus by RAPD analysis (Fig. 3). This revealed that the silage isolates had almost identical chromosomal structures that were distinct from those of $B$. circulans and $B$. firmus. In summary, strain $171544^{\mathrm{T}}$-like isolates constitute a separate taxon within Bacillus, however the precise phylogenetic position of these bacteria could not be solved with certainty.

\section{Helix 49, an idiosyncrasy for the $171544^{\top}$-like strains}

Previously, it has been reported that strain $171544^{\mathrm{T}}$ has an unusually long insertion sequence in the penultimate stem-loop structure of the 16S rRNA gene (De Silva et al., 1998) and, in this study, strains $1 \mathrm{HR}, 2 \mathrm{HR}, 3 \mathrm{HR}$ and $4 \mathrm{HR}$ were found to have identical structures. These extensions are positioned in helix 49 using the nomenclature of Van de Peer et al. (1996) from positions 1449 to 1454 according to 


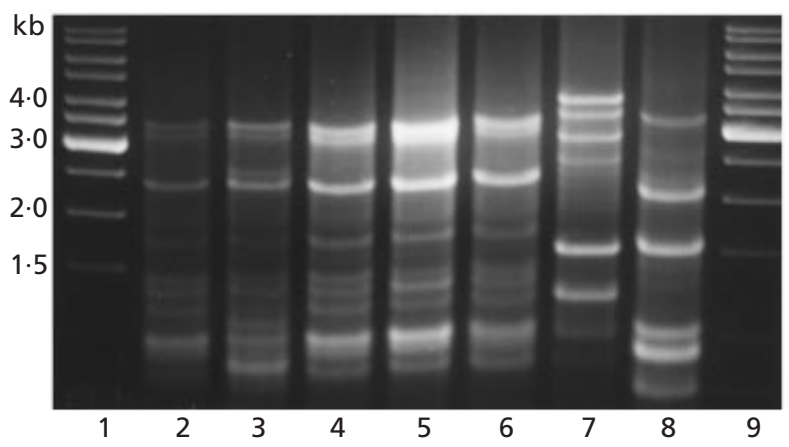

Fig. 3. RAPD patterns generated from chromosomal DNA of the silage isolates and reference strains of $B$. circulans and $B$. firmus. Lanes: 1, 1-kb DNA ladder; 2 , strain $171544^{\top} ; 3$, 1HR; 4, $2 \mathrm{HR} ; 5,3 \mathrm{HR} ; 6,4 \mathrm{HR} ; 7, B$. circulans DSM $11^{\top} ; 8, B$. firmus DSM $12^{\top} ; 9,1-\mathrm{kb}$ ladder.

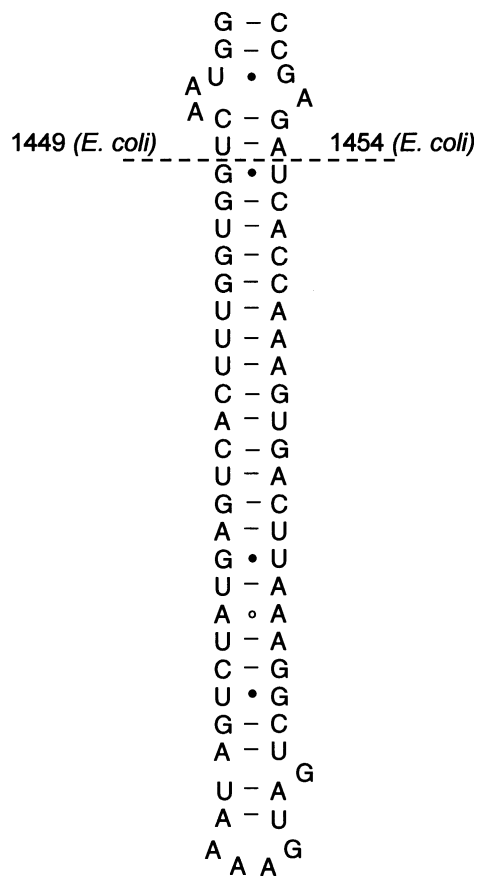

Fig. 4. Sequence of the $49-n t$ insertion in helix 49 of the $16 \mathrm{~S}$ rRNA genes of Bacillus siralis strain $171544^{\top}$ and relatives showing a most likely base-pairing structure. The dashed line denotes the origin of the extension as compared to E. coli and most other prokaryotes. The actual nucleotide positions according to E. coli are 1449 and 1454 .

Escherichia coli numbering (Brosius et al., 1978). The total length of the extension was found to be 49 nt and a plausible secondary structure, deciphered by applying comparative analysis, is shown in Fig. 4. In this model, all but one of the inserted bases, a purine forming a unilaterally bulged residue, can be defined as constituents of a stem structure terminated by a tetraloop. Almost all of the base pairs $(83 \%)$ are of the canonical Watson-Crick type. Searching GenBank using this insertion sequence resulted in no significant

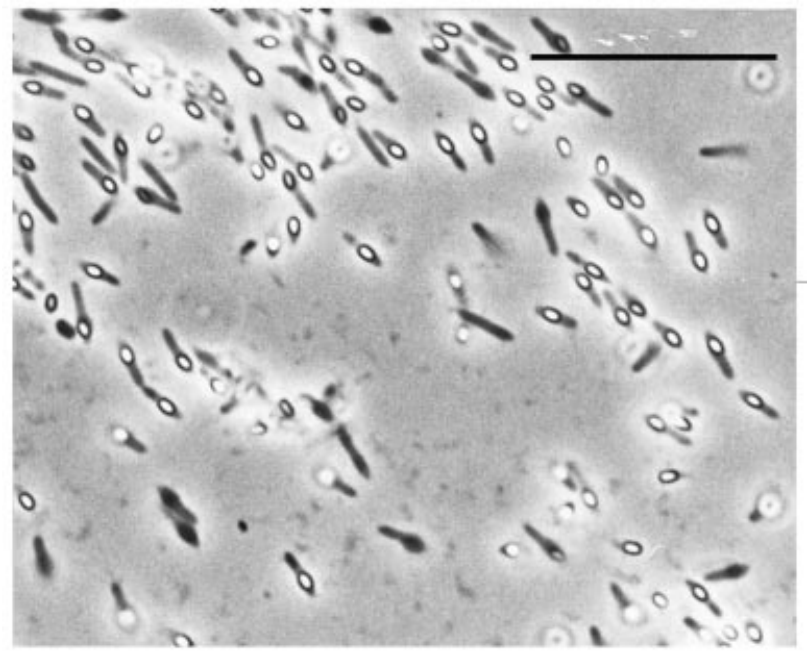

Fig. 5. Phase-contrast photomicrograph of Bacillus siralis strain $171544^{\top}$ after growth on NYSM agar for $36 \mathrm{~h}$. Bar, $10 \mu \mathrm{m}$.

similarity to any deposited sequence from the Bacteria, Archaea or Eucarya. Only 13 small subunit rRNA sequences showed this type of attribute, and the insertion present in the phylogenetically closely related sediment clone BPC094 (Fig. 2) showed the highest sequence similarity to that of strain $171544^{\mathrm{T}}$, namely $49 \%$.

\section{Phenotypic characteristics of Bacillus strain $171544^{\top}$ and relatives}

Bacillus strains $171544^{\mathrm{T}}$, 1HR, 2HR, 3HR and 4HR were morphologically and physiologically homogeneous. Cells were rod-shaped being $2 \cdot 0-3 \cdot 0 \mu \mathrm{m}$ in length by about $0 \cdot 5-0 \cdot 8 \mu \mathrm{m}$ in diameter and stained Gram-positive. After incubation for $24 \mathrm{~h}$ on BHI agar, large colonies $(3-5 \mathrm{~mm}$ in diameter) were formed which were brown to light brown in colour. The colony surface was granular but glistening and shiny. On NYSM agar, the colonies were $1-3 \mathrm{~mm}$ in diameter and lighter in colour. Spores first appeared on NYSM agar after $24 \mathrm{~h}$ and were oval, located subterminally to terminally in a swollen sporangium (Fig. 5).

Strain $171544^{\mathrm{T}}$ and the related silage isolates were examined for a range of biochemical and physiological characters (Table 1). They were strict aerobes that did not produce acid from sugars or sugar alcohols (see species description). They were negative for the Voges-Proskauer reaction but they could use nitrate as a terminal electron acceptor. All of the strains hydrolysed aesculin, casein, gelatin and tributyrin, but not starch. Growth was observed in $7 \% \mathrm{NaCl}$, but not $10 \%$. The bacteria did not grow at temperatures above $50{ }^{\circ} \mathrm{C}$. All strains were resistant to discs containing $5 \mu \mathrm{g}$ erythromycin and $1 \mathrm{U}$ penicillin $\mathrm{G}$, but were generally sensitive to a range of other antibiotics including chloramphenicol $(25 \mu \mathrm{g})$, gentamicin $(10 \mu \mathrm{g})$, novobiocin $(5 \mu \mathrm{g})$ streptomycin $(10 \mu \mathrm{g})$ and 
tetracycline $(25 \mu \mathrm{g})$. These features distinguished the silage isolates from phylogenetically related species such as $B$. benzoevorans, B. circulans and B. firmus (Table 1).

\section{DISCUSSION}

Endospore-forming bacteria predominate in the upper layers of silage bins, but are less common in the bulk anaerobic regions (Dutkiewicz et al., 1989). Although several studies have enumerated total aerobic endospore-forming bacteria, the diversity of species has received scant attention. In a recent study, $B$. pumilus, Bacillus cereus, B. circulans, Bacillus licheniformis, Bacillus sphaericus, Brevibacillus choshinensis and Paenibacillus validus were associated with aerobic spoilage of maize silage (Inglis et al., 1999). However, our previous study (De Silva et al., 1998) and the results presented here show that silage is a rich source of novel endospore-forming bacteria.

Phylogenetic analysis revealed that Bacillus strain $171544^{\mathrm{T}}$ and relatives were members of the genus Bacillus (Fig. 2). The high representation of soil clones in the phylogenetic neighbourhood of strain $171544^{\mathrm{T}}$ suggests that these bacteria are part of a larger community of endospore-forming bacteria that inhabit grassland soils from which they gain access to silage. The closest relative to strain $171544^{\mathrm{T}}$ was $B$. circulans, which shared $97.2 \%$ 16S rDNA sequence similarity. This is on the $97 \%$ upper limit for species delineation, as suggested by Stackebrandt \& Goebel (1994), and supports the classification of these bacteria in distinct species. Further evidence for the separation of these bacteria from $B$. circulans and $B$. firmus was provided by their distinctive RAPD patterns.

The isolates were characterized at the molecular level by an insertion in the 16S rRNA genes. This insertion is almost certainly present in all copies of the rrs gene because there were no frameshifts in the sequencing electropherograms such as those caused by the heterogeneities in $16 \mathrm{~S}$ rRNA genes found in B. sporothermodurans (Pettersson et al., 1996). The actual extension was found to result in an almost doubling of the stem length of helix 49 (Fig. 4) and, since it was identical in all strains, the oligonucleotide primer $1452 \mathrm{R}$ was found to be reliable for the detection of $171544^{\mathrm{T}}$-like strains (Fig. 1a).

Very few other rDNA sequences shared a similar structure, e.g. the sediment clone BPC094, some Desulfotomaculum and Thermoanaerobacter species and some mitochondrial rDNAs. Since strain $171544^{\mathrm{T}}$ and the sediment clone BPC094 are close phylogenetic relatives (Fig. 2), it is tempting to speculate in a shared origin of this insertion in these two 16S rRNA genes. Reasons for this would be that they are of identical length, they form stable base pairing (BPC094 data not shown) and they both protrude from the same nucleotide positions. However, while the overall 16S rRNA gene sequence similarity between Bacillus strain $171544^{\mathrm{T}}$ and clone BPC094 is $95.7 \%$, the nucleotide similarity of the insertion sequences in helix 49 is only $49 \%$ indicating that if they do have a common origin, these insertions are subject to rapid evolutionary change. It has not been demonstrated whether the insertion is present in the $16 \mathrm{~S}$ rRNA molecule or removed by processing, as it is for example in Clostridium paradoxum (Rainey et al., 1996) and Salmonella typhimurium (Mattatall \& Sanderson, 1996), because of difficulties obtaining reverse transcriptase products from purified rRNA (data not shown).

Bacillus strain $171544^{\mathrm{T}}$ and the four silage isolates form a homogeneous taxon as defined by the $16 \mathrm{~S}$ rRNA insertion, genomically (by RAPD analysis) and physiologically. Morphologically, the cells resemble those of $B$. circulans, but they can be readily differentiated from the latter by virtue of their strict aerobic metabolism. Moreover, the organisms can be readily distinguished from other phylogenetically related species using traditional phenotypic tests (Table 1). It is therefore proposed that these bacteria be given species status within the genus Bacillus as Bacillus siralis.

\section{Description of Bacillus siralis sp. nov.}

Bacillus siralis (si.ra'lis. L. masc. n. sirus grain pit, silo; L. adj. siralis belonging to the silo).

Cells are rod-shaped, $2 \cdot 0-3 \cdot 0 \mu \mathrm{m}$ in length by about $0.5-0.8 \mu \mathrm{m}$ in diameter and occur singly. Grampositive. Spores are oval, located subterminally to terminally in a swollen sporangium. Colonies on BHI agar after incubation for $24 \mathrm{~h}$ are $3-5 \mathrm{~mm}$ diameter, brown to light brown in colour. The colony surface is granular, but glistening and shiny, circular, entire. On nutrient agar, the colonies are smaller $(1-3 \mathrm{~mm}$ in diameter), pale and opaque. Aerobic, catalase- and oxidase-positive. Nitrate in broth is reduced to nitrite, but not nitrogen gas. Arginine is not hydrolysed (strain $1 \mathrm{HR}$ is an exception) and citrate is not used as carbon source. Resistant to erythromycin $\left(5 \mu \mathrm{g} \mathrm{ml}^{-1}\right)$. Butanediol (Voges-Proskauer test) is not produced and acids are not produced from a range of sugars and sugar alcohols including arabinose, cellobiose, fructose, galactose, glucose, glycerol, inositol, lactose, maltose, mannitol, mannose, melibose, raffinose, rhamnose, ribose, salicin, sorbitol, sucrose, trehalose and xylose. Aesculin, casein and gelatin, but not starch, are hydrolysed. Grows in $7 \% \mathrm{NaCl}$, but not $10 \%$, and at $50^{\circ} \mathrm{C}$, but not $55^{\circ} \mathrm{C}$. Contains characteristic inserts of 49 bases in the distal region of the 16S rRNA genes. The full sequence of the $16 \mathrm{~S}$ rRNA gene has database accession number AF071856. Source: silage. The type strain $\left(171544^{\mathrm{T}}\right)$ has been deposited in the National Collection of Industrial and Marine Bacteria as NCIMB $13601^{\mathrm{T}}$ and in the Collection de 1'Institut Pasteur as CIP $106295^{\mathrm{T}}$.

\section{ACKNOWLEDGEMENTS}

Bertil Pettersson is indebted to the Swedish Foundation for Strategic Research. We thank Mrs M. Barker for technical 
assistance particularly with the RAPDs analysis and photomicroscopy and Professor Hans G. Trüper for advice in formulation of the name.

\section{REFERENCES}

Aquino de Muro, M., Mitchell, W. J. \& Priest, F. G. (1992). Differentiation of mosquito-pathogenic strains of Bacillus sphaericus from non-toxic varieties by ribosomal RNA gene restriction patterns. J Gen Microbiol 138, 1159-1166.

Altschul, S. F., Madden, T. L., Schaffer, A. A., Zhang, J., Zhang, Z., Miller, W. \& Lipman, D. J. (1997). Gapped BLAST and PSI-BLAST: a new generation of protein database search programs. Nucleic Acids Res 25, 3389-3402.

Borneman, J., Skroch, P. W., O'Sullivan, K. M., Palus, J. A., Rumjanek, N. G., Jansen, J. L., Nienhuis, J. \& Triplett, E. W. (1996). Molecular microbial diversity of an agricultural soil in Wisconsin. Appl Environ Microbiol 62, 1935-1943.

Brosius, J., Palmer, M. L., Kennedy, P. J. \& Noller, H. F. (1978). Complete nucleotide sequence of a $16 \mathrm{~S}$ ribosomal RNA gene from Escherichia coli. Proc Natl Acad Sci USA 75, 4801-4805.

Burgin, A. B., Parodos, K., Lane, D. J. \& Pace, N. R. (1990). The excision of intervening sequences from Salmonella $23 \mathrm{~S}$ ribosomal RNA. Cell 60, 405-414.

Claus, D. \& Berkeley, R. C. W. (1986). Genus Bacillus Cohn 1872. In Bergey's Manual of Systematic Bacteriology, vol. 2, pp. 1105-1139. Edited by P. H. A. Sneath, N. S. Mair, M. E. Sharpe \& J. G. Holt. Baltimore: Williams \& Wilkins.

De Silva, S., Pettersson, B., Aquino de Muro, M. \& Priest, F. G. (1998). A DNA probe for the detection and identification of Bacillus sporothermodurans using the $23 \mathrm{~S}-16 \mathrm{~S}$ rDNA spacer region and phylogenetic analysis of some field isolates which form highly heat resistant endospores. Syst Appl Microbiol 21, 398-407.

Dutkiewicz, J., Olenchock, S. A., Sorenson, W. G., Gerencser, V. F., May, J. J., Pratt, D. S. \& Robinson, V. A. (1989). Levels of bacteria, fungi, and endotoxin in bulk and aerosolized corn silage. Appl Environ Microbiol 55, 1093-1099.

Felsenstein, J. (1993). PHYLIP (Phylogeny Inference Package) version 3.51c. Seattle: Department of Genetics, University of Washington.

Felske, A., Wolterink, A., Van Lis, R. \& Akkermans, A. D. L. (1998). Phylogeny of the main bacterial 16S rRNA sequences in Drentse A grassland soils (the Netherlands). Appl Environ Microbiol 64, 871-879.

Gordon, R. E., Haynes, W. C. \& Pang, C. H.-N. (1973). The Genus Bacillus. Agriculture Handbook no. 427. Washington, DC: United States Department of Agriculture.

Inglis, G. D., Yanke, L. J., Kawchuk, L. M. \& McAllister, T. A. (1999). The influence of bacterial inoculants on the microbial ecology of aerobic spoilage of barley silage. Can J Microbiol 45, $77-87$.

Jukes, T. H. \& Cantor, C. R. (1969). Evolution of protein molecules. In Mammalian Protein Metabolism, vol. 3, pp. 21-132. Edited by H. N. Munro. New York: Academic Press.

Linton, D., Dewhirst, F. E., Clewley, J. P., Owen, R. J., Burnens, A. P. \& Stanley, J. (1994a). Two types of $16 \mathrm{~S}$ rRNA gene are found in Campylobacter helveticus: analysis, applications and characterization of the intervening sequence found in some strains. Microbiology 140, 847-55.
Linton, D., Clewley, J. P., Burnens, A., Owen, R. J. \& Stanley, J. (1994b). An intervening sequence (IVS) in the 16S rRNA gene of the eubacterium Helicobacter canis. Nucleic Acids Res 22, 1954-1958.

Maidak, B. L., Cole, J. R., Parker, J.C. T. \& 11 other authors (1999). A new version of the RDP (Ribosomal Database Project). Nucleic Acids Res 171, 171-173.

Mattatall, N. R. \& Sanderson, K. E. (1996). Salmonella typhimurium possesses three distinct $23 \mathrm{~S}$ rRNA intervening sequences. J Bacteriol 178, 2272-2278.

Mattatall, N. R. \& Sanderson, K. E. (1998). RNase III deficient Salmonella typhimurium LT2 contains intervening sequences (IVSs) in its 23S rRNA. FEMS Microbiol Lett 159, 179-185.

Patel, B. K. C., Love, C. A. \& Stackebrandt, E. (1992). Helix 6 of the 16S rRNA of the bacterium Desulfotomaculum australicum exhibits an unusual structure idiosyncrasy. Nucleic Acids Res 20, 5483 .

Pettersson, B., Lembke, F., Hammer, P., Stackebrandt, E. \& Priest, F. G. (1996). Bacillus sporothermodurans, a new species producing highly heat-resistant endospores. Int J Syst Bacteriol 46, 759-764.

Pichinoty, F., Asselineau, J. \& Mandel, M. (1984). Charactérisation biochemique de Bacillus benzoevorans sp. nov., une nouvelle espèce filamenteuse, engainée et mésophile dégradant divers acides aromatiques et phénols. Ann Microbiol/Inst Pasteur 135B, 209-217.

Priest, F. G., Goodfellow, M. \& Todd, C. (1988). A numerical classification of the genus Bacillus. J Gen Microbiol 134, 1847-1882.

Rainey, F. A., Ward-Rainey, N. L., Janssen, P. H., Hippe, H. \& Stackebrandt, E. (1996). Clostridium paradoxum DSM $7308^{\mathrm{T}}$ contains multiple 16S rRNA genes with heterogeneous intervening sequences. Microbiology 142, 2087-2095.

Ralph, D. \& McClelland, M. (1994). Phylogenetic evidence for horizontal transfer of an intervening sequence between species in a spirochete genus. J Bacteriol 176, 5982-5987.

RDP-II (1999). R.D.P. Release 7.0. East Lansing, MI: Michigan State University.

Saitou, N. \& Nei, M. (1987). The neighbor-joining method: a new method for reconstructing phylogenetic trees. Mol Biol Evol 4, 406-425.

Skurnik, M. \& Toivanen, P. (1991). Intervening sequences (IVSs) in the $23 \mathrm{~S}$ ribosomal RNA genes of pathogenic Yersinia enterocolitica strains. The IVSs in Y. enterocolitica and Salmonella typhimurium have a common origin. Mol Microbiol 5, 585-593.

Smith, S. (1992). GDE: Genetic Data Environment, version 2.2. Ann Arbor, MI: Millipore Imaging Systems.

Stackebrandt, E. \& Goebel, B. M. (1994). Taxonomic note: a place for DNA-DNA reassociation and 16S rRNA sequence analysis in the present species definition in bacteriology. Int $J$ Syst Bacteriol 44, 846-849.

Van Camp, G., Van de Peer, Y., Nicolai, S., Neefs, J. M., Vandamme, P. \& De Wachter, R. (1993). Structure of $16 \mathrm{~S}$ and 23S ribosomal RNA genes in Campylobacter species: phylogenetic analysis of the genes and presence of internal transcribed spacers. Syst Appl Microbiol 16, 361-368.

Van de Peer, Y., Chapelle, S. \& De Wachter, R. (1996). A quantitative map of nucleotide substitution rates in bacterial 16S rRNA. Nucleic Acids Res 24, 3381-3391. 